10. Yamashita H, Onodera S, Imamoto T, Obara A, Tanazawa S, Takashio T, et al. Functional and geometrical interference and interdependency between the right and left ventricle in cor pulmonale: an experimental study on simultaneous measurement of biventricular geometry of acute right ventricular pressure overload. Jpn Circ J. 1989;53:1237-44.

11. Belenkie I, Horne SG, Dani R, Smith ER, Tyberg JV. Effects of aortic constriction during experimental acute right ventricular pressure loading. Further insights into diastolic and systolic ventricular interaction. Circulation. 1995;92:546-54.

12. Apitz C, Honjo O, Friedberg MK, Assad RS, Van Arsdell G, Humpl T, et al. Beneficial effects of vasopressors on right ventricular function in experimental acute right ventricular failure in a rabbit model. Thorac Cardiovasc Surg. 2012;60:17-23.

13. Assad RS, Atik FA, Oliveira FS, Fonseca-Alaniz MH, Abduch MC, Silva GJ, et al. Reversible pulmonary trunk banding. VI: Glucose-6-phosphate dehydrogenase activity in rapid ventricular hypertrophy in young goats. $J$ Thorac Cardiovasc Surg. 2011;142(5):1108-13, 1113.e1.

14. Budev M, Arroliga A, Wiedemann H, Matthay RA. Cor pulmonale: an overview. Semin Respir Crit Care Med. 2003;24:233-44.

15. Handoko ML, de Man FS, Allaart CP, Paulus WJ, Westerhof N, VonkNoordegraaf A. Perspectives on novel therapeutic strategies for right heart failure in pulmonary arterial hypertension: lessons from the left heart. Eur Respir Rev. 2010;19:72-82

16. Banerjee D, Haddad F, Zamanian RT, Nagendran J. Right ventricular failure: a novel era of targeted therapy. Curr Heart Fail Rep. 2010;7:202-11.

17. Haddad F, Ashley E, Michelakis ED. New insights for the diagnosis and management of right ventricular failure, from molecular imaging to targeted right ventricular therapy. Curr Opin Cardiol. 2010;25:131-40.
18. Bogaard HJ, Natarajan R, Henderson SC, Long CS, Kraskauskas D, Smithson L, et al. Chronic pulmonary artery pressure elevation is insufficient to explain right heart failure. Circulation. 2009;120:1951-60

19. Janicki JS, Brower GL, Gardner JD, Forman MF, Stewart JA Jr, Murray DB, et al. Cardiac mast cell regulation of matrix metalloproteinase-related ventricular remodeling in chronic pressure or volume overload. Cardiovasc Res. 2006;69: 657-65.

20. Weber KT, Janicki JS, Shroff SG, Pick R, Chen RM, Bashey RI. Collagen remodeling of the pressure-overloaded, hypertrophied nonhuman primate myocardium. Circ Res. 1988;62:757-65.

21. Stewart DJ, Levy RD, Cernacek P, Langleben D. Increased plasma endothelin-1 in pulmonary hypertension: marker or mediator of disease? Ann Intern Med. 1991;114:464-9.

22. Giaid A, Yanagisawa M, Langleben D, Michel RP, Levy R, Shennib H, et al. Expression of endothelin-1 in the lungs of patients with pulmonary hypertension. $N$ Engl J Med. 1993;328:1732-9.

23. Langleben D, Dupuis J, Langleben I, Hirsch AM, Baron M, Senécal JL, et al. Etiology-specific endothelin-1 clearance in human precapillary pulmonary hypertension. Chest. 2006;129:689-95.

24. Awad AE, Kandalam V, Chakrabarti S, Wang X, Penninger JM, Davidge ST, et al Tumor necrosis factor induces matrix metalloproteinases in cardiomyocytes and cardiofibroblasts differentially via superoxide production in a PI3K $\gamma$-dependent manner. Am J Physiol Cell Physiol. 2010;298:C679-92.

25. Maejima Y, Okada H, Haraguchi G, Onai Y, Kosuge H, Suzuki J, et al. Telmisar$\tan$, a unique ARB, improves left ventricular remodeling of infracted heart by activating PPAR gamma. Lab Invest. 2011;91:932-44.

\title{
COMMENTARY
}

\section{Aortic constriction and the relevance of physiologic research}

\section{Emile A. Bacha, MD}

A casual reader might be tempted to skip over the article by Apitz and colleagues in this issue, dismissing it as irrelevant to clinical practice. The title is also somewhat offputting because "aortic constriction" evokes only bad images in the mind of any cardiac surgeon. In fact, however, this elegant yet traditional cardiac physiology experiment shows that chronic aortic constriction not only improves right ventricular (RV) function in the setting of chronic RV pressure overload but also leads to less maladaptive RV remodeling. This article does inform on highly relevant themes, such as ventricle-ventricle interaction, timing of RV remodeling, and the molecular signature of

\footnotetext{
From the Department of Cardiac Surgery, Morgan Stanley Children's Hospital of New York-Presbyterian, Columbia University, New York, NY.

Disclosures: Author has nothing to disclose with regard to commercial support.

Received for publication May 28, 2012; accepted for publication June 12, 2012; available ahead of print July 23, 2012

Address for reprints: Emile A. Bacha, MD, Columbia University, Department of Cardiac Surgery, Morgan Stanley Children's Hospital of New York-Presbyterian,

New York, NY 10032 (E-mail: eb2709@columbia.edu).

J Thorac Cardiovasc Surg 2012;144:1501

$0022-5223 / \$ 36.00$

Copyright (C) 2012 by The American Association for Thoracic Surgery

http://dx.doi.org/10.1016/j.jtcvs.2012.06.026
}

$\mathrm{RV}$ profibrotic reactions. It may also open the door to a very untraditional way of managing the remodeled RV. The problem of the hypertrophied yet not decompensated $\mathrm{RV}$ is typically solved by an early repair of the anatomy, such as early repair of tetralogy of Fallot for example. No one would consider "banding" the aorta to allow for reverse RV remodeling. What, however, about the thick, fibrotic RV in an older patient with unrepaired pulmonary stenosis? Should we consider, akin to pulmonary artery banding and left ventricular training in an older patient with transposition of the great arteries, a period of aortic afterload increase to reposition the septum and maybe reverse some of the myocardial profibrotic signaling? What about managing the failing postoperative RV? In the setting of good left ventricular function, and in the absence of any current drugs that can directly increase RV contractility, systemic afterload increase by pharmacologic means may in fact have a role to play.

At a time when therapeutic answers are being sought mostly in genetics and tissue engineering, this study reminds us that physiologic research remains an essential and vital tool. 